Inceleme Makalesi - Review Article

\title{
Davranışsal Çalışma Ekonomisi Alanında Güncel Gelişmeler
}

\section{Current Developments in Behavioral Labor Economics Area}

\author{
Ö. Hakan ÇAVUŞ* \\ 0000-0002-0124-8812
}

\author{
Sosyal Güvenlik Dergisi / Journal of Social Security \\ Cilt: 11 Sayı: 2 Y1l: 2021 /Volume: 11 Issue: 2 Year: 2021 \\ Sayfa Aralığı: 288-307 / Pages: 288-307 \\ DOI: 10.32331/sgd.1049003
}

\section{ÖZ}

Davranışsal ekonomi, özellikle ana akım neoklasik ekonomi teorisinin yeterince ele almadığ 1 birey davranışlarının özellikleri ile ilişkisini açıklamak amacıyla standart ekonomi sistemini daha geniş bir perspektiften ele almaya işçi bir alan haline gelmiştir. Gözlem ve deneylere dayanarak gerçekleştirilen araştırmalar, sınırlı rasyonellik çerçevesinde birey davranışlarını irdelemeyi esas almaktadır. Davranışsal ekonomi, ekonomik aktörlerin karmaşık ve kısıtlı birey özelliklerini yansıtan piyasaları inceleyen bir alandır. İnsanın davranışsal etkileşimleri, işgücü piyasalarına da yansıdığ ekonomi, çalışma ekonomisi ile ilgili alanlarda yeni ve önemli kanitlar sunmaktadır. $\mathrm{Bu}$ çalışmada davranışsal ekonominin önemli çalışma alanları arasında yer alan sosyal tercihlerin rolü kapsamında hakkaniyet ve karșllıklı ödün ilkesi temelinde ele alınan hediye değişimi teorisi ile ilgili alan çalışmaları değerlendirilmiştir. Çalışma ekonomisinin içeriğini oluşturan konuların davranışsal temellere dayandığı, sürekli etkileşimlerin ortaya çıkmasında hakkaniyet unsurunun önemli rol oynadığı, insanların kazanmak yerine ellerindekini kaybetmemeyi önemsedikleri, işçilerin yüksek ücret almaları durumunda çabalarında artış olduğu çalışmamızda elde edilen bazı bulgular arasında yer almaktadır.

Anahtar Sözcükler: Davranışsal ekonomi, çalışma ekonomisi, davranışsal çalışma ekonomisi, hediye değişim teorisi, sosyal tercihler

\section{ABSTRACT}

Behavioral economics has become a field that tries to handle the standard economics system from a broader perspective in order to explain its relationship with the characteristics of individual behavior, which is not adequately addressed by the mainstream Neo-Classical economic theory. Studies based on observations and experiments are based on examining individual behaviors within the framework of limited rationality. Behavioral economics is a field that studies markets that reflect the complex and limited individual characteristics of economic actors. Since human behavioral interactions are also reflected in labor markets, behavioral economics provide important evidence in areas related to labor economics. In this study, field studies related to gift exchange theory, which is handled on the basis of the principle of equity and mutual compromise within the scope of the role of social preferences, which are among the important fields of study of behavioral economics, are evaluated. Some of the findings of our study are that the subjects that make up the content of the labor economy are based on behavioral foundations, that the element of fairness plays an important role in the emergence of continuous interactions, that people care not to lose what they have instead of winning, and that there is an increase in the efforts of workers if they receive high wages.

Keywords: Behavioral economy, labor economy, behavioral labor economy, gift-exchange theory, social preferences

Önerilen atıf şekli: Çavuş, Ö. Hakan (2021). Davranışsal Çalışma Ekonomisi Alanında Güncel Gelişmeler. Sosyal Güvenlik Dergisi (Journal of Social Security). 11(2). 288-307.

• Geliş Tarihi/Received: 24/05/2021 • Güncelleme Tarihi/Revised: 25/11/2021 • Kabul Tarihi/Accepted: 27/12 /2021

\footnotetext{
Doç. Dr., Manisa Celal Bayar Üniversitesi, İktisadi ve İdari Bilimler Fakültesi,

Çalışma Ekonomisi ve Endüstri İlişkileri Bölümü, ohcavus@gmail.com
} 


\section{GíRIŞ}

Davranışsal ekonominin birçok tanımı bulunmaktadır. Davranışsal ekonomi yaklaşımının marjinalist devrimin sınırlayıcı varsayımlarına karşı bir tepki olduğu ve ekonomi aktörlerinin davranışları ile ilgili gerçekçi varsayımları ortaya çıkarmayı amaçladığı vurgulanmaktadır. Davranışsal ekonomi yaklaşımının diğer sosyal bilimlerle ilgili kavramları, ana akım ekonomi tarafından kullanılan kâr ve yarar maksimizasyonu modellerinin mevcut sistemini değiştirip zenginleştirmek için kullanıldığı görülmektedir (Demirel ve Artan, 2016: 9-10). Davranışsal ekonomi kavramı, genel olarak psikoloji bilimi ile ekonomi bilimi arasındaki bağlantıları inceleyen araştırma alanını ifade etmektedir (Mullainathan ve Thaler, 2000: 2; Gul, 2008; 12; DellaVigna, 2009: 317 ). Davranışsal ekonomi ile ilgili tanımların birçoğunun ortak ana unsurunun; homo economicus olarak ifade edilen rasyonel, bencil, ileriye dönük bir yararı maksimize peşinde koşan bireyin, ana akım ekonomik modellerle çelişen insanın karar verme sürecini araştırmak için psikoloji biliminde kullanılan içgörü yaklaşımını ve unsurlarını birarada değerlendirmesi olduğu görülmektedir (Smelser ve Swedberg, 2013: 9-10). Kişilik psikolojisinin ana kavramlarından birisi olan içgörü yaklaşımı ile birlikte çalışma ekonomistleri, büyük ölçüde davranışsal ekonomi alanında geliştirilen deneysel yöntemleri de kullanmaktadırlar. Temelde dürtme (nudge), seçenek mimarisi (choice architecture) ve özgürlükçü babacılık (libertarian paternalism) kavramlarıyla ele alınan davranışsal içgörü yaklaşımı; insanların gerçekte nasıl seçim yaptıklarını keşfetmek amacıyla psikoloji, bilişsel bilimler ve sosyal bilimlerden elde edilen bilgileri ampirik olarak test edilmiş sonuçlarla birleştiren politika oluşturucu bir yaklaşım olarak ortaya çıkmıştır (Özdemir, 2019: 2; Thaler ve Sunstein, 2017: 99-113).

Psikolojik ve sosyolojik faktörler özellikle işgücü piyasaları açısından da büyük önem taşıdığ 1 için davranış teorilerinden elde edilen içgörülerle birlikte çalışma ekonomisi alanında birçok yeni teori ve kavram geliştirilmiştir (Kaufman, 1999: 364). Bu kapsamda; sosyal etkileşim, risk ve belirsizlik tercihleri ve zamanlar arası karar verme, ücret-çaba ilişkisi, ücretin belirlenmesi, beşeri sermaye birikimi, arama davranışı, ücret ve kariyer hareketliliği veya zamanlararası hareketlilik, işgücü arzı kararları gibi konular özellikle davranışsal çalışma ekonomisinde deneysel çalışmalar yapılarak geliştirilen kavramlar arasında yer almaktadır (Tagiev ve Ignatov, 2016: 85-86).

Çalışma ekonomisinin içeriğini oluşturan konuların davranışsal temellere dayandığı çalışmamızın temel hipotezini oluşturmaktadır. Çalışmamızda, davranışsal ekonomi ile ilgili çalışmaların gelişimiyle birlikte davranışsal çalışma ekonomisinin hem teorik hem de saha deneylerine dayalı olarak nasıl geliştiği incelenmiş ve Neo-klasik ekonomi yaklaşımları ile davranışsal çalışma ekonomisi yaklaşımı arasında farklılıklar karşılaştırılmıştır. Çalışmamızda, hediye değişim teorisi çerçevesi ile birlikte davranışsal ekonominin temel unsurları arasında yer alan; sosyal tercih, referans bağımlılı̆̆ hizmet eden önyargılar ve işgücü arzı kavramlarının çalışma ekonomisi ile bağlantıları teorik ve uygulamalara dayanan çalışmaların sonuçları değerlendirilmiştir. Ayrıca bu çalışmada, davranışsal çalışma ekonomisi ile ilgili neredeyse yok dencek sayıda çalışmanın yapılmış olması nedeniyle bu alandaki çalışmaların teorik ve uygulama sonuçlarına dikkat çekilmesi amaçlanmıştır. 


\section{I- DAVRANIŞSAL ÇALIŞMA EKONOMISI ALANINDAKİ GELIŞMELERIN NEDENLERI}

Davranışsal ekonomi ile ilgili çalışmaların özellikle son otuz yıl içinde çalışma ekonomisi ile ilgili konuları derinden etkilemesi nedeniyle davranışsal çalışma ekonomisi alanının gelişmekte olduğu görülmektedir. Bu gelişmenin nedenlerini beş ana başlık altında toplayabiliriz. Bunlardan ilki, çalışma ekonomisi alanında davranışsal içgörüler üzerine kurulan veya bunları birleştiren çok sayıda yayının yapılmasıdır. Bu yayınların yoğunlaştığı ve bir literatürün oluştuğu alanlardan birisi de çalışmamızın konusu içinde yer alan işgücü piyasasında hediye değişimi teorisi (oyunu) üzerine oluşturulan teorik ve uygulamalı çalışmalardır (Akerlof, 1982: 545-552). İkinci neden, bireysel karar alma süreçlerine ve insan etkileşimi üzerine odaklanan mikro işgücü kavramı ile ilgili çalışmaların artmasıdır. Bu çalışmalar sosyal etkileşimi belirleyen, insan doğasının davranışsal ekonomi teorisine entegre edilmiş ana yönlerini yani standart olmayan tercihleri, standart olmayan inançları ve standart olmayan karar verme süreçlerini incelemektedir (DellaVigna, 2009: 317; Borghans vd.,2008: 975; Almlund vd., 2011: 82). Doğal olarak, davranışsal ekonomi ile ilgili çalışmalar, işgücü piyasasındaki davranışların ve bu davranışların sonuçlarının mikro ekonomik analizlerini makro düzeydeki işgücü sorunları ile birlikte ele alınabilmesine olanak vermiştir (Akerlof, 2003: 28-30; Akerlof ve Shiller, 2009: 168). Bu noktada sosyal tercih, işçilerin ve işverenlerin standart olmayan temel tercihlerinden birisi olarak ortaya çıkmış ve özellikle sosyal tercihler ve hakkaniyet meselelerinin işgücü piyasası sorunları üzerindeki etkisi üzerine odaklanılmasına neden olmuştur (Fehr vd., 2009: 360).

Bazı saha çalışmalarıyla standart olmayan karar verme davranışının, önyargılar çerçevesinde işçilerin iş arama ve eğitim kararlarını etkilediği ispatlanmıştır. İşgücü piyasalarındaki standart olmayan inançların; işçilerin asil-vekil ilişkilerindeki aşırı güven ve işgücü piyasalarına yönelik aşırı karamsarlıkları veya aşırı iyimserlikleri nedeniyle oluştuğu iddia edilmiştir. Asil-vekil ilişkisinin ana unsurunu oluşturan vekalet teorisi akımından bir tanesi olan asil-vekil yaklaşımı, işçi-işveren ilişkilerini de incelemektedir (Hamilton ve Kashlak, 1999: 169). Vekil, yetki veren kişilerin amaçlarını gerçekleştirmek için işçi durumunda iken, asil ise vekili kendi amaçları doğrultusunda çaba harcamak için motive eden kişi/kişileri ifade etmektedir. Ekonomi bilimi açısından değerlendirildiğinde, vekil bireysel çıkarları doğrultusunda motive olmakta ve rasyonel davranışlar sergileyerek ve riskten kaçınma eğilimindedir. Vekalet veren (asil), çeşitli teşvikler aracılığıyla vekili motive edebilmektedir (Karayel, 2006: 7-8). Asil-vekil ilişkisi yaklaşımı, vekil tarafından ifa edilen bir işin, asil tarafından yönetilen bir teşvik mekanizmasının karşılığı olduğu ve vekilin ortak normları veya gayri resmi anlaşmaları dikkate almadan her zaman kendi yararının peşinden gittiğini varsaymaktadır (Dodlova ve Yudkevich, 2009: 25-26). Bununla birlikte, mevcut birçok asilvekil ilişkisi türü, standart teşvik sözleşmeleri teorisinin sınırlarının ötesine geçmektedir. İşçinin gösterdiği performans nedeniyle ödeme yapma yaklaşımı, üstler ve astlar arasındaki veya sadece astlar arasındaki ilişkilerde, başkasına da yararlı olabilme davranışını açıklayamamaktadır. Örneğin, pratikte bir işçinin bazı durumlarda kendine özgü vicdani değerleri çerçevesinde gerekenden daha fazla çalışarak çaba harcadığı gözlemlenebilirken, bir işverenin bu işçiye piyasadaki emsal işçi ücretinin üzerinde ödeme yaptığı çok defa gözlenmiştir (Akerlof, 1982: 550). Bu durumu açıklamanın ve çalışmanın devam ettiği süre boyunca ortaya çıkan verimsiz risk paylaşımı sorununa bir çözüm olarak hediye değişimi teorisi ile bilinen asil-vekil ilişkisine alternatif bir yaklaşım geliştirildiği öne sürülmüştür. Bu yaklaşım ile temsilcilerin (katılımcıların) birbirlerine karşı iyimser şekilde yaklaştıkları ve hediye adı altında karşılıklı olarak icra edilen belirli eylemlerin veya hizmetlerin ifa edilebildiği gözlenmiştir. Başka bir deyişle, temsilciler iyiliğe nezaketle karşılık vermek için gayri resmi bir anlaşma yapmaktadırlar (Cameer, 2006: 190-191). 
Davranışsal Çalışma Ekonomisi Alanında Güncel Gelişmeler

Davranışsal çalışma ekonomisinin gelişmesinin üçüncü nedeni, davranışsal ekonomi alanında saha çalışması olarak uygulanan deneysel yöntemlerin çoğalmasıdır. Davranışsal çalı̧̧ma ekonomisi alanına yapılan ilk katkılar, laboratuvar çalışmaları olarak değerlendirilen işgücü piyasalarında sosyal tercihin rolü üzerine yürütülen deneysel kanıtlardan elde edilmiştir. Çalışma ekonomistleri, deneysel yöntemlerin insan motivasyonunun itici güçlerini ve doğasını ortaya çıkardığını ispatlamışlardır. Özellikle son yıllarda, anket veya görüşme yoluyla bilgi toplanmasına dayalı yapılan araştırmalar, geleneksel çalışma ekonomisinin aynı zamanda işgücü piyasalarında tekrarlanan insan etkileşimlerinin özellikleriyle de ilgilenmek zorunda olduğunu ortaya çıkarmıştır. Bu olgunun, insanların çalışma ekonomisi alanında neyin davranışsal olup olmadığı konusunda fikir birliği içinde olmamalarının nedeni olarak görüldüğü ekonomistler tarafindan iddia edilmektedir (Dohmen vd., 2009: 600; WinterEbmer, 2014; 1-2; Berg, 2006;465). Ayrıca araştırmacılar, alan deneylerinin ekonomideki diğer yaklaşımlarla birleştirilmesi yoluyla iç görünün en yüksek düzeyde geliştirildiğini öne sürmektedirler (Charness ve Kuhn, 2011: 229). Çalışma ekonomisinin gelişmesinin dördüncü nedeni, çalışma ekonomistlerinin genellikle işçilerin ve şirketlerin insan etkileşimlerine dayalı tekrarlanan kararlarını araştırmalarından kaynaklanmaktadır (Borghand vd., 2018: 990). Çalışma ekonomisinin gelişmesinin beşinci nedeninin de eksik sözleşmelere dayalı olarak işçi ve işveren arasındaki ilişkilerin kuruluyor olmasıdır. İnsan etkileşimlerinin birçok boyutu, özellikle de işçinin çabası tam olarak belirlenememektedir (Fehr vd.,2009: 340; Levitt vd., 2007: 160).

Ekonomi biliminde sözleşmeler hukuku alanında sözleşme teorileri ile ilgili çok tartışmalı bir alan bulunmaktadır. Eksik sözleşme olarak ifade edilen teori, sözleşmeler yapılırken sözleşmelerin konularıyla ilgili gelecekte ortaya çıkabilecek her olasılığın sözleşme yapılırken öngörülememesi nedeniyle bu olasılıkların ortaya çıkması halinde ne yapılacağının sözleşme yapılırken belirlenemeyeceğini ifade etmektedir. Dahası, sözleşmenin tarafları, daha sonra ilişkilerinde karşılıklı olarak yarar sağlayacak yeniden müzakerelere asla girmeyeceklerini taahhüt edemezler (Altmann vd., 2014: 40-41). Son dönemlerde davranışsal çalışma ekonomisi alanındaki araştırmaların çoğu eksik sözleşmeler çerçevesinde işveren ve işçinin davranışını modellemek amacıyla hediye değişimi, adalet normları ve karşılıklı ödün ilkesinin rolüne odaklanmıştır (Grosman vd, 1986: 700). Dolayısıyla, insan etkileşimlerinin ve motivasyonunun doğası hakkındaki varsayımlarla ilgili olarak standart Neo-klasik ekonominin varsayımlarından önemli farklılıklar içeren davranışsal ekonomi yaklaşımı, işçilerin ve işverenlerin gözlemlenen davranışlarını açıklamaya yardımcı olmaktadır.

\section{II- SOSYAL TERCIHLERIN ROLÜ}

Sosyal tercih, insanların ekonomik faaliyetlerini yürütürken birbirleriyle etkileşim halinde başkalarının kazanımlarına veya refahına dikkat etme eğilimini ifade eder ve bu bağlamda Neo-klasik yaklaşımın öne sürdüğü insanların bencil olduğu varsayımından ayrılmaktadır. Sosyal tercihler; azami sosyal fedakârlık, karşılıklı ödün ilkesi, hakkaniyet ve diğer birbirine bağlı tercih türlerini içermektedir (Cameer, 1997: 410). Laboratuvarlarda ve alanda çeşitli yöntemler kullanılarak sosyal tercihlerin farklı yönleri modellenerek test edilmiştir. Ortaya çıkan kanıtlar, sürekli tekrarlanan etkileşimlerin ortaya çıkmasında hakkaniyet konusunun önemli rol oynadığını ortaya koymuştur. Sosyal tercihler yaklaşımının bir kısmını oluşturan azami sosyal fedakârlık kavramı; karşılıklı ödün ilkesi, hakkaniyetin kanıtı, ültimatom oyunu, diktatör oyunu, kamu malı oyunu ve güven oyunlarından elde edilmiştir (Camerer vd., 2003; 1225 Kahneman vd., 1986: 290; Ledyard, 1995: 182; Gachter vd., 2012: 1352, Berg vd., 1995: 131). Yine yapılan çalışmalar sonucu, sosyal tercihlerin ortaya çıkmasında, bireylerin önemli bir bölümünün oldukça bencil davranışlar sergilediklerini ortaya 
koymuştur (Fehr vd., 2009: 362). Pozitif karşılıklı ödün ilkesi, karşılıklı iyi niyete dayalı eylemlere karşı aynı şekilde olumlu bir tepkiyi öngörürken negatif karşılıklı ödün ilkesine göre düşmanca eylemlerin cezalandırılması gerektiğini ifade etmektedir (Fehr ve Gachter, 2000; 170). Pozitif ve negatif karşılıklı ödün ilkesi ile ilgili yapılan deneyler sonucunda elde edilen verilere göre, negatif karşılıklı ödün ilkesinin pozitif karşılıklı ödün ilkesinden daha güçlü olduğu görülmüştür (Charness, 2004: 677; Cox vd., 2008: 14). Ayrıca sosyal tercihleri önemseyen bireylerin, haksız davranışları cezalandırma yönünde davrandıkları görülmüştür (Bolton ve Ockenfels, 2000; 170; Charness ve Rabin, 2002: 825; Dufwenberg ve Kirchsteiger, 2004: 280; Falk ve Fischbacher, 2006; 304).

Standart olmayan tercihler çerçevesinde, adalet normlarının ve sosyal karşılaştırmaların, işçi ücretlerini ve sarfedilen çabayı/eforu nasıl etkilediği incelenmiştir. Ayrıca işçilerin, aldıkları ücretlerin, adil bir ücret olarak düşündükleri ücret düzeyinin altına düştüğünde çalışma çabalarını azaltacaklarını öne süren adil ücret hipotezinin ne ölçüde geçerli olduğunu araştıran çalışmalar sonucu önemli gelişmeler ortaya çıkmıştır (Akerlof ve Yellen, 1990: 261).

Sosyal fedakârlık kavramı ile sosyal tercihler arasında da önemli etkileşimler bulunmaktadır. Özellikle çalışma sırasında yoğun çabanın sarfedilmesi diğer işçiler açısından dışsallık yarattığında, işçiler arasındaki azami sosyal fedakârlık kaygısının işçilerin daha az çaba göstermelerine neden olabildiği görülmüştür. Yapılan bir alan çalışmasında, işçilere parça başı ücret yerine performansa göre ücret ödendiğinde, işçilerin göreceli performanslarının negatif dışsallığını bir dereceye kadar içselleştirdiklerini ve bu nedenle verimliliklerinin düştüğü görülmüştür (Bellemare ve Shearer, 2009: 237). Bir başka alan çalışmasında, bir hasat sezonunda bir meyve çiftliğinden elde edilen iş̧̧ilerin verileri incelendiğinde, verimlilikteki değişikliklerin ücret planındaki değişikliklere göre farklılaştı̆̆ını ortaya koymuştur. Söz konusu ücret planında değişiklik yapılarak ücret ödeme şeklinin göreceli performans yerine sabit parça fiyatına göre belirlendiğinde her işçinin ortalama üretkenliğinin \%52 oranında arttığı tespit edilmiştir. İşçilerin, grup içinde samimi oldukları arkadaşlarının ücretleri arttırıldığında diğer işçilerin de verimliliğinin arttığı ve bu etkinin küçük gruplarda daha güçlü olduğunda göreceli teşviklerin dışsallığının daha fazla içselleştirildiği ortaya konmuştur. Bununla birlikte, göreceli teşviklere bağlı olarak ölçülen verimliliğin yalnızca işçilerin birbirlerini izleyebildiklerinde önemli ölçüde daha düşük gerçekleştiği görülmüştür. Bu durum, işçilerin sosyal tercihlerinin, onların başkalarına karşı kayıtsız şartsız azami sosyal fedakârlık yapmadıklarını göstermektedir (Bandiera, vd., 2005: 920-923).

Genel olarak işgücü piyasasına ait verilerin elde edilmesinde, homojen ve heterojen unsurların yanısıra yasal ve kurumsal değerler de belirleyici olmaktadır. Örneğin hem işçiler ve hem de şirketler, şirkette uygulanan asgari ücret politikası hakkında bilgi sahibi olduklarında birçok şirket duruma göre asgari ücretin üzerinde ücret ödeyebilmektedir (Falk ve Ichino, 2006: 41). Bununla birlikte yapılan çalışmalarda, asgari ücret politikasının işçiler tarafından tam olarak bilinmediği durumda, şirketlerin işçilere daha az ödeme yaptığı ve çok sayıda şirketin sadece asgari ücret düzeyinde ücret ödedikleri görülmüştür (Wang, 2012: 959). Bu sonuçlar, sosyal tercihlerin, tüm şirketleri ücret ödeme konusunda kayıtsız şartsız cömert davranmaya yöneltmediğini kanıtlamaktadır. Dolayısıyla, işgücü piyasaları ile ilgili sonuçları öngörebilmenin ana koşulunun, davranış biçimlerini diğer ilgili sosyal tercihlerin veya bencil davranış kalıbının etkilediği faktörlerin, koşulların ve kurumsal düzenlemelerin anlaşılması olduğu sonucuna ulaşılmaktadır. Sonuç olarak, sosyal tercihlerin uzun vadeli iş ilişkilerinde davranışları ne zaman ve nasıl yönettiğine dair değerlendirmelere ihtiyaç bulunmaktadır (Gneezy ve List, 2006: 1371). 
Davranışsal Çalışma Ekonomisi Alanında Güncel Gelişmeler

\section{III- REFERANS BAĞIMLILIĞI, GÖRECELİ GELİR VE KAYIPTAN KAÇINMA}

Referans bağımlılı̆̆ı, kişinin yararının hem mutlak hem de göreceli seviyelere bağlı olduğu anlamına gelmektedir (Kahneman ve Tversky, 1979: 277). Bu kavram, kişinin görev pozisyonunun diğer işçilerle veya kişinin zaman içinde kendi performansıyla karşılaştırılmasında ortaya çıkan göreceli düzey kavramıyla ifade edilmektedir. Göreceli karşılaştırma; işgücü arzını, ücret düzeylerini, çaba gösterme düzeyini ve optimal teşvik sistemlerinin tasarımını etkilediği için işgücü piyasaları açısından geniş kapsamlı alan çalışmaları yapılarak yeni çıkarımlar yapılmasına olanak sağlamaktadır (Neumark ve Postlewaite, 1998: 170; Cohn vd., 2014: 885; Bartling ve Siemens, 2010: 601). Göreceli karşılaştırma, işçilerin ücret ödemeleriyle ilgili memnuniyetlerini etkilemektedir. Şirketlerdeki teşvik tedbirlerinin bir parçası olarak, göreceli konum, parasal olmayan teşvik olarak görülen bir statü veya konumsal yarar sağlamaktadır (List ve Rasul, 2011: 157). Konuyla ilgili olarak California Üniversitesi işçileri arasında yapılan bir çalışmada, meslektaşlarının ücretlerine ilişkin bilgilerin ifş̧a edilmesinin, ortalama ücret altında ücret alanlar arasında iş tatmininin azalmasına ve işten ayrılma niyetlerinde artışa neden olduğu görülürken ortalama ücretin üzerinde ücret alan işçilerin bundan etkilenmediğini ortaya koymuştur (Card vd., 2012: 990). Yine deneysel bir çalışmada, mutlak gelir düzeyi dikkate alındığında göreceli gelirin, gelir tatminini etkilediği görülmüştür (Liu ve Wang, 2015: 399).

Standart Neo-klasik model, insanların çıkarı için sadece mutlak getiri seviyesinin önemli olduğunu varsayarken, kanıtlar bu seviyelerin bir referans seviyesine göre değerlendirildiğini göstermektedir. Referans seviyesi, kişinin kendi kazancını diğer insanların kazançlarıyla kıyaslaması sonucu ortaya çıkmaktadır (Frank, 2005: 139; Olson vd., 2014: 11). Çeşitli ampirik çalışmalar, gelir karşılaştırmalarının yaşam doyumunu ve karar verme süreçlerini de etkilediğini göstermiştir (Luttmer, 2005: 970; Clark vd., 2010: 417). Referans seviyesi, Kahneman ve Tversky tarafından Beklenti Teorisi'nde öne sürülen referans bağımlılığ 1 ve kayıptan kaçınma kavramlarıyla tutarlı olan kişinin performansının kendi geçmiş performansıyla karşılaştırılması sonucu da ortaya çıkabilmektedir. Bu durum, işçilerin ücret tercihlerini etkilemektedir (Kahneman ve Tversky, 1979: 273). Genel olarak beklenti teorisine göre, insanlar kazanmak yerine ellerindekini kaybetmemeyi önemsemektedirler, kayıp ve kazancın eşdeğer olduğu durumda ise kayıptan kaçınma yolunu tercih etmektedirler. İnsanların risk ve belirsizlik altındayken irrasyonel davranarak beklenen yararı maksimum yapmak yerine kayıptan kaçındıkları öne sürülmektedir (Aktan, 2018: 350).

İşçiler arasındaki göreceli karşılaştırmanın; şirket içi ücret yapısı, işçilerin morali ve zaman içindeki ücret değişiklikleri üzerinde etkisi bulunmaktadır. Göreceli gelirden kaynaklanan olası dışsallık nedeniyle, şirketlerin ücret ölçeklerini daraltması ve şirketlerin, şirket içindeki ücret eşitsizliğini azaltması veya ücret gizliliğini sürdürmesi gerekebilmektedir (Stark ve Hyll, 2011: 360; Charness ve Kuhn, 2011: 360). İnsanların referans gruplarını seçme yöntemleri, işgücü piyasasının sonuç verileri üzerinde güçlü bir etkiye sahiptir. Genel olarak, insanlar kendilerine benzeyen diğer insanlarla karşılaştırma yapma eğilimindedir. Bu durum, iç ve dış işgücü piyasalarındaki ücret dinamikleri arasındaki farkı açıklamaya yardımcı olmaktadır (Fehr vd., 2009: 370). Yeni bir şirkete iş başvurusunda bulunan işçilerin, bir şirketin ücret teklifinin hakkaniyetli olup olmadığını çoğunlukla işgücü piyasasındaki emsal ücret düzeyine göre değerlendirdikleri görülmüş̧ür. Bunun tersine, şirkette çalışmakta olan işçiler, kendilerine önerilen ücret değişikliklerinin hakkaniyetini statüye göre değerlendirebilmektedirler. Buna göre şirket, çalışan işçilerin ücretlerini değiştirmeden işe yeni giren işçilerin ücretlerini işgücü piyasası koşullarına göre ayarlayabilmektedir. Sonuç olarak, referans bağımlılığı ve kayıptan kaçınma, nominal ücretlerin daha düşük seviyelere 
düşmesine engel olmaktadır (Ockenfels vd., 2015: 1600; Agell ve Lundborg, 2003: 18). Aksine, işçilere verimliliğe bağlı olmayan beklenmedik bir ikramiye verildiğinde işçilerin sonraki verimlilik düzeyi üzerinde önemli ve olumlu bir etkiye neden olduğu görülmüştür (Bellemare ve Shearer, 2009; 239; Gneezy ve List, 2006: 1377). Referans bağımlılı̆̆1, işçilerin gelir hedeflerini belirlediklerinde ve geleneksel modellerin öngördüğü gibi getirilerini optimize etmedikleri durumlarda işçilerin çalışma sürelerini etkilemektedir. $\mathrm{Bu}$ sonuçlar, taksi şoförleri ve bisikletli kuryeler üzerinde yapılan çalışmalar sonucu elde edilmiştir (Camerer vd., 1997: 460; Farber, 2008: 1077; Fehr ve Goette, 2007: 301).

\section{IV- GEÇİCI ÜCRET DEĞİŞIKLİKLERINIIN DAVRANIŞSAL SONUÇLARI}

İşçilerin geçici ücret değişikliklerine karşı tepkileri ile ilgili çok sayıda araştırma yapılmıştır (Charness vd. 2012: 2362; Farber, 2008: 1071). Örneğin, New York kentinde faal olan taksi şoförlerinin elde ettikleri kazançları ile çalışma saatleri arasında negatif bir korelasyon bulunmuştur. Bu sonuç, güçlü bir referans bağımlılığı biçimi olan gelir hedeflemesi ile tutarlı olduğu halde pozitif bir durum olan neoklasik zamanlar arası işgücü arzı modeliyle tutarlı olmadığını ispatlamıştır. New York taksi şoförleri ile ilgili yapılan diğer çalışmalardan elde edilen benzer verileri, işgücü arzı modelinin başka bir önemli çıkarımını, yani işi durdurmanın gelir kaybı tehlikesini artırıp artmadığını test etmek için kullanılmış ve taksi şoförlerinin gün içinde meydana gelen gelir kaybına yönelik risk oranı bulgusunun gelirle tutarlı olmadığı sonucuna varılmıştır (Fehr ve Goette, 2007: 300; Crawford ve Meng, 2011; 1920; Abeler vd., 2011: 1310; Chou, 2002: 27).

Ana akım zamanlar arası işgücü arzı modelini eleştirenler ile söz konusu modeli savunanlar arasındaki tartışmalar sonucu dört önemli bulgu elde edilmiştir. Buna göre; ilk bulgu, geçici ücret artışına paralel olarak işçi sayısının artması sonucu işgücü arzının, standart zamanlar arası işgücü arzı modelinin tahminleriyle tutarlı olduğu yönündedir (Barmby ve Dolton, 2009: 18). İkinci bulguya göre, yoğun oranda gerçekleşen referans bağımlılığı, işgücü arzını etkilemektedir ve gelir hedefleri, beklenmedik geçici ücret artışlarına tepki olarak bireylerin davranışlarını daha az çalışmaya itiyor gibi görünmektedir (Camerer vd.,1997: 421; Chou, 2002: 30, Farber, 2008: 1078; Crawford ve Meng, 2011: 1927). Üçüncü bulguya göre, işçi davranışı önemli ölçüde heterojen özellikler göstermektedir (Doran, 2009: 21). Dördüncü bulguya göre, Neo-klasik zamanlar arası işgücü arzı modelinden daha iyi tahminler veren referansa bağlı tercihlere sahip işgücü arzı modelleri geliştirilmiştir.

Araştırmacılar, başlangıçta elde edilen verilere göre, referans noktalarının (gelir hedeflerinin) hergün değiştiğini ve bu değişimleri tahmin etmenin çok zor olması nedeniyle değişen işgücü arzını tahmin etmek için modellere kayıptan kaçınma unsurunun dahil edilmesinin beklentiye dayalı referans noktalarının varsayımını destekleyen deneysel kanitlar nedeniyle yararlı olduğunu tespit etmişlerdir (Farber, 2005: 1079; Köszegi ve Rabin, 2006: 1140; Crawford ve Meng, 2011: 1920). Bu noktada, kayıptan kaçınma kavramı çerçevesinde davranışsal ekonominin günümüzdeki en önemli temsilcileri arasında yer alan Tversky ve Kahneman, bireylerin kayıp halinde hissettikleri acının, aynı miktardaki kazancın hissettireceği hazza göre iki kat fazla olduğunu, bu nedenle insanların tercihlerini kayıptan kaçınma duygusunun belirlediğini iddia etmişlerdir (Kamilçelebi, 2019: 43). New York şehri taksi sürücüleri üzerinde yapılan bir alan araştırmasında, beklentiye dayalı içsel gelir ve saat hedefleri olan bir modelin verileri daha iyi açıkladığı görülmüştür (Abeler vd., 2011: 1317; Köszegi ve Rabin, 2006: 1145). Ayrıca hediye değişim teorisi (oyunu) ile etkileşim halinde işleyen hakkaniyet ilkesi ile ilgili çalışmalardan elde edilen kanıtlara göre, iş ilişkilerinde bazı durumlarda negatif (zararlı) karşılıklı ödün ilkesi ortaya çıkabilmektedir. Örneğin, ABD'deki bir lastik üretim fabrikasındaki iş̧̧ilerin greve gitme kararını verdikleri süreçte daha kalitesiz 
ve kusurlu lastik üretiminin arttığı, bu durumun işçilerin haksız muamele olarak algıladıkları duruma karşı negatif karşılıkla tepki vermelerinden kaynaklandığı ortaya konmuştur (Mas, 2006: 800); Kube, vd.,2012: 1652; Krueger ve Mas, 2004: 260).

\section{V- KENDİSINE HIZMET EDEN ÖNYARGILAR}

\section{A- Genel Olarak}

Kendisine hizmet eden önyargı, insanların yargıda bulunurken, bilinçsizce kendileriyle daha ilişkili olan tarafı tercih etme eğiliminde oldukları gerçeğini ifade etmektedir. Önyargılar, standart olmayan inançlara yol açabilmektedir (DellaVigna, 2009: 325). Kendine hizmet eden önyarg1, insanların kendi başarılarını ve yeteneklerini abartmasına, bilgileri kendi çıkarları doğrultusunda elde etmesine ve yorumlamasına, hakkaniyeti adil ve tarafsız standartlar yerine kişisel çıkar standardına dayalı olarak tanımlamasına neden olabilmektedir. İnsanlar ekonomik etkileşimlerinde hakkaniyeti önemserken, karar alma biçimleri değiştikçe farklı hakkaniyet kuralları arasında geçiş yapabilmektedirlerler (Frohlich vd., 2004: 100). Deneysel çalışmalar, hakkaniyet kurallarındaki tutarsızlığın temelde kendine hizmet eden önyargıdan kaynaklandığına dair kanıtlar sunmuştur (Ubeda, 2010: 91).

Kendine hizmet eden önyargı, bilginin elverişli olması durumundan ve bilgi bütünlügünün geliştirilmesinden etkilenir (Babcock vd., 1995: 480). Amerikalı ve Çinli katılımcıların yer aldığı bir kültürler arası müzakere deneyinde, insanların yargıda bulundukları nesnenin tanımını bilmediklerinde, iki tarafın hakkaniyet yargılarının birbirinden farklı olmadığını göstermiştir. Bununla birlikte, söz konusu nesnenin açık bir şekilde tanımlanması durumunda, kendine hizmet eden hakkaniyet yargısının ortaya çıktığı ve fikirlerin farklılaşmasına yol açtığı görülmüştür (Kriss vd.,2011: 610).

\section{B- İşçi ve İşveren İlişkilerinde Kendisine Hizmet Eden Önyargıların Rolü}

Kendisine hizmet eden önyargıların içerikleri birbirinden farklıdır. İlk olarak, adil bir ücretin unsurlarının neler olduğuna dair bir önyargının oluşumu ile ilgili yürütülen bir deneysel çalı̧̧mada, bir katılımcının diğerlerinden daha uzun süre çalışması nedeniyle çalışma süresine göre daha yüksek bir adil ücret talep etme eğiliminde olduğunu ancak diğerlerinden daha kısa bir süre çalıştığında ise diğerlerinin çalışma zamanı için daha düşük bir adil ücret ödenmesi yönünde öneride bulunma eğiliminde olduğunu ortaya koymuştur. Bu eğilim, insanların adil ücret konusundaki yargılarının esas olarak kişisel çıkarlara dayandığını göstermektedir (Messick ve Sentis, 1979: 420). Diğer yandan, hakkaniyette tarafsızlığın bozulması, işverenler ve işçiler arasındaki çatışmaların artmasına ve toplu iş görüşmelerinin sonuçlanmamasına neden olabilmektedir. Ücret pazarlığına ilişkin toplu iş görüşmelerinde; müzakereciler, hakkaniyet ve karşılıklı ödün ilkesi kadar ekonomik faktörleri de dikkate alırlar. Bununla birlikte, sendikaların ve işverenlerin bakış açılarına göre adil ücretlerin belirlenme kriterleri arasında önemli farklılıklar bulunmaktadır. Toplu iş görüşmelerinin tarafları genelde birbirlerinin tekliflerini hemen kabul etmeyerek karşılıklı teklifleri adil olmayan bir talep olarak kabul etmektedirler. Bu psikolojik bakış açısı, müzakerecilerin sahip oldukları hakkaniyet seviyesinin altındaki koşullara karşı çıkmalarına neden olmakta ve iş görüşmelerinin çıkmaza girmesine yol açmaktadır (Babcock \& Loewenstein, 1997: 15). Yapılan çalışmalar sonucu elde edilen kanıtlar, müzakerecilerin hakkaniyet yargıları arasındaki farkın derecesinin işçi grevleriyle ilişkili olduğunu ortaya koymuştur (Babcock vd., 2012: 9). 


\section{VI- HEDIYY DEĞIŞ̧iM TEORİSİ (OYUNU)}

\section{A- Genel Olarak}

Hediye değişimi teorisi (oyunu), Akerlof ve Yellen'in çalışma ilişkilerini modellemek için geliştirdikleri bir teoridir. Bu teori, işverenlerin işçilerine piyasa denge ücretinin üzerinde ücret ödemeleri halinde işçilerin de karşılık olarak daha fazla performans/efor ortaya koyacakları görüşüne dayanmaktadır. Bu teori kapsamında, işçiler kendilerine işverenleri tarafından verilen hediyenin (yüksek ücret) karşılığında işverenlerine başka bir hediyeyle (fazla performans/efor) karşılık vermektedirler (Akerlof, 1982: 543-544). Bu ilişki sosyal tercihlerde karşılıklılık kavramı ile açıklanmaktadır. İşçilere daha yüksek ücret verilip verilmeyeceğine önce işveren karar vermektedir. Ardından ücret artışı talebi olduğunda işçinin daha fazla çaba/efor göstermesi beklenir. İşveren fazladan ücret öderse ve işçi daha fazla çaba sarf ederse, o zaman her iki taraf da kazanmış olacaktır. (Fehr vd., 2009: 370, Akerlof ve Yellen,1990: 270). Akerlof'un çalışmasının temelinde, hediye alışverişi teorisi (oyunu) olarak adlandırılan deneysel bir oyunun geliştirilmesiyle birlikte hediye alışverişi teorisine yönelik çalışmalar ivme kazanarak söz konusu literatürü oldukça genişletmiştir (Fehr vd., 1993: 438).

Hediye değişimi teorisi, günümüzde, işçilerin çabaları ile ücretleri arasındaki ilişkileri ve özellikle de gayrı iradi işsizliği açıklamak için kullanılmaktadır. Bu teori kapsamında, işgücü piyasalarında kullanılan iş sözleşmeleri "kısmi hediye değişimi” olarak tanımlanmaktadır. Bunun nedeni de ücret artışı karşısında işçinin daha çok çaba sarfetmeme ihtimalinin olması ve gerçek hayatta işçilerin gereken asgari çalışma süresini aşmaları halinde şirketlerin piyasadaki emsal işçi ücretinden daha fazla ücret ödediklerinin görülmesidir. Bu modele göre, bunun nedeni, iş̧̧inin çabasının yalnızca çabanın kendisine, ücret oranına ve işsiz işçinin hem kendi yararına hem de çaba normuna da bağlı olmasıdır. Dolayısıyla, bu normları etkilemek için şirketler daha fazla ödeme yapabilmektedirler (Akerlof, 1982: 552).

Hediye değişim teorisi, sosyolojik unsurlar ile yeni ekonomik analizleri, ücret katılıklarını açıklamak amacıyla bu unsurları ekonomik bir temelde birleştirir. Böylece, söz konusu sosyolojik model; neoklasik kavramlarla açıklanamaz görünen olayları açıklayabilmenin dışında şirketlerin daha az verimli olan işçileri neden işten çıkarmadıklarını, bu durumdaki işçilere neden parça başına ücret ödemekten kaçındıklarını ve şirketlerin işyerindeki fazla çalışma esaslarının unsurlarını belirleyebildiğini ortaya koymaktadır. Ayrıca hediye değişimi teorisi, sosyal kategorilerin ve normların; insanların kendilerini ve diğerlerini sosyal kategorilere ayırdıklarını, sosyal kategorilerin ve normların otomatik olarak birbirlerine bağlandıklarını, farklı sosyal kategorideki insanların farklı davranmalarının gerekliliğini de ispatlamıştır (Akerlof, 1982: 554). İşçilerin şirket uygulamalarına yönelik bağ lılığ 1 , işgücü verimliliği için önemli bir faktördür (Akerlof, 1984: 80). Verimlilik ücreti, işgücü piyasasının tarafları arasındaki normatif uzlaşmanın da bir ifadesi olarak yorumlanabilmektedir (Akerlof, 1982: 551).

Yapılan deneysel çalışmalarda, şirket performansına bağlı ödemelerin, terfi firsatlarının veya diğer teşviklerin sunulmadığı bir şirkette çalışan işçilerin verimliliklerinin kontrol edilmesinin kolay olduğu görülmüştür. Neo-klasik teoride, şirketlerin standart üretim hedeflerini neden yükseltmediği ve üretken olmayan işçilerin neden işten çıkarılmadıkları sorgulanmamaktadır (Akerlof 1982, 548).

Grupların çalışma davranışına ilişkin sosyolojik perspektif, belirli bir çalışma grubunun normlarının sonuç olarak işçilerin verimlilikleri için etkili faktör olduğunu ortaya koymaktadır. $\mathrm{Bu}$ varsayım, neo-klasik perspektifin hediye alışverişi yaklaşımı içinde genişletilmesi için başlangıç noktası olarak kabul edilebilmektedir. İşçinin verimliliği, 
Davranışsal Çalışma Ekonomisi Alanında Güncel Gelişmeler

standart çalışma verimliliğini karşıladığı sürece çalışma süreleri serbestçe belirlenmektedir. Standardın üzerindeki her ek verimlilik miktarı, işçiden işverene hediye olarak yorumlanabilmektedir. $\mathrm{Bu}$ hediye takası, ticari ilişkiler veya karşılıklılık olarak adlandırılan işveren-işçi ilişkileri bağlamında değerlendirilebilmektedir (Akerlof, 1982, 549). Bu durumda, işçilerin diğer işçilere ve işverene karşı dostça duygular geliştirdiği görülmüştür. Böylece, şirketlerin hedeflerine ulaşırken şirket yöneticilerinin işçilerin duygularını ve ihtiyaçlarını anlamak, saygı duymak ve dikkate almak unsurlarına dayalı politikalar geliştirebileceklerdir (Akerlof, 1982, 550).

Normların etkisinin hediye değişimi teorisine dahil edilmesi, ücret ve çabanın genel yarar fonksiyonuna ek bir değişken olarak değerlendirilmesine neden olmuştur. Bu değişken, diğerlerinin yanı sıra işsizlik oranı seviyesine, işsizler için desteğin yüksekliğine ve diğer işçilerin ilgili yarar fonksiyonuna bağlıdır. Örneğin, işveren bireysel performansa dayalı kazançları çoğu zaman işçi ücretlerine yansıtmazlar ancak grup halinde çalışan işçilerin kazançlarına yansıtabilirler. Bireysel anlamda işçinin yararı, diğer işçiler üzerindeki baskı azaldığında artmaktadır. Şirketten gelen bir armağan olarak yorumlanabilecek bu davranış, sosyolojik bir kavramı da yansıtmakta olup çalışma gruplarının farklı durumlarda, üyeleri belirli standartları ve tutumları paylaşan tek bir birim olarak tepki verdiklerini göstermektedir (Bowles vd., 2001: 156). Ayrıca, işçinin adalet duygusu bu noktada değerlendirilmektedir. İşçilerin hem kendi performansları hem de aynı seviyedeki diğer işçiler bağlamında ücreti adil olarak görmeleri için bazı kriterler gerekmektedir (Akerlof, 1982: 560). Bu kriterleri; bireyin algılanan adil ücreti, bireyin önceki dönemlerdeki fiili ücreti, bireyin cari ve önceki dönemlerde referans düzeyinde başkalarına ödenen ücret, cari ve önceki dönemlerde referans düzeyindeki işçilerin işsizlik yardımları, mevcut ve önceki dönemlerde referans düzeyindeki işsiz sayısı ve bireyin cari ve önceki dönemlerdeki çalışma kuralları şeklinde sıralayabiliriz (Akerlof, 1982: 561).

\section{B- Hediye Değişim Teorisinin Etkileri}

Hediye değişimi teorisi, işverenin işçilerin davranışlarındaki değişikliklere tepkisi ile gayrı iradi işsizliğin varlığını tanımlamaktadır. İşçiler, adil davranıldığını hissettikleri sürece daha verimli çalışırlar. Piyasadaki emsal işçi ücretinin üzerinde ödenen ücretler, gayrı iradi işsizliğe neden olur. Denge durumunda gayrı iradi işsizlik varsa, şirketlerin piyasa denge ücretinden daha fazlasını ödemeyi istemeleri gerekir. Bu durum, herhangi bir verimliliğe dayalı ücret teorisinin ana unsurudur (Akerlof, 1984, 79).

Verimliliğe dayalı ücreti hipotezinin altında yatan fikir, kazanç katılığının ve gayrı iradi işsizliğin mikroekonomik temelleri ile ilgilidir. Kazanç katılığı, gayrı iradi işsizlere, piyasada geçerli emsl ücret miktarından daha düşük bir ücret verilemeyeceğini öngörmektedir. $\mathrm{Bu}$ durum, işgücü piyasasının işçi ve işverenden oluşan tarafların öngördüğü risk tercihleri arasındaki sistematik farklılıkların ortaya çıkmasına engel olur ve ayrıca emek verimliliği ile gerçek ücretler arasındaki pozitif korelasyonun nedensellik ilişkisini açıklar (Akerlof, 1984: 80). İşverenler, verimliliğe dayalı ücret ödeme biçimiyle kârlarını arttırma imkanına sahip olduklarından, ücret tekliflerini işgücü piyasasındaki tam istihdam durumuna göre uyarlamakla ilgilenirler. İşverenlerin asıl kriteri, ulusal ekonomiye bağlı olmadan verimli üretim başına işçilik maliyetlerini en aza indiren kârlara ilişsindir. Kâr, piyasa denge seviyesinin üzerindeyse, işverenin işçi çalıştırmaya devam edebilecektir. Aslında, işgücü piyasasının dengesi, gayrı iradi işsizlik ile açıklanabilmektedir. Sonuç olarak şirket, işçilerinin verimliliğini azaltacağı için verimliliğe dayalı işçi ücretini tam istihdam düzeyine düşürmemektedir. Verimlilik düzeyinde bir azalma meydana geldiğinde bu azalma, düşen ücret maliyetleri ile dengelenemez (Sesselmeier ve Swedberg, 2013: 313). Verimliliğe dayalı 
ücret teorilerinin temel varsayımı, kusurlu ve asimetrik bilgi nedeniyle teşvik tedbirlerinin uygulanmasının zorunluluğunu öne sürmesidir (Weiss, 1990, 20).

Genel argümana göre, artan ücret oranı nedeniyle işgücü talebi azalmaktadır. İşverenler, işçi ücretini düşük ücret miktarına göre belirledikleri için bu nokta işgücü talep miktarını belirlemektedir. Bu düşük ücret seviyesi işverenin beklentilerini karşılamayacağından daha düşük bir ücret seviyesinde daha büyük bir işgücü talebi gerçekleştirilse bile, talep edilen emek miktarı değişmeyecektir. İşsizliğin boyutu, bu nedenle işgücü arzının düzeyine bağlıdır. Verimliliğe dayalı ücreti hipotezi, asil-vekil sorunuyla da ilgilidir. Bu noktada işçinin performansının işveren tarafından tespit edilmesi ve işçinin kontrol edilmesinin mümkün olmaması önemli sorunlar olarak ortaya çıkmaktadır (Kranton, 1996: 840). Verimliliği arttırmaya yönelik olarak uygulanan bireysel parasal teşvikler, uygulamada verimliliği arttırmamaktadır. Bu durumun üç nedeni vardır. Bunlardan ilki, işçilerin tek başlarına çalışmaları ile kıyaslandığında ekip halinde çalışmaları durumunda daha verimli üretim yapmalarıdır. İkinci olarak, birçok işçinin aynı anda birkaç işi birarada yürütmesinin zorunluluğudur. $\mathrm{Bu}$, sadece bazı görevlerin ödüllendirilmesinin, bu görevler üzerinde yoğunlaşmaya ve diğer görevlerin ihmal edilmesine yol açacağı anlamına gelir. Üçüncüsü, işçilere göreceli performans karşılığında ücret ödendiğinde, ortaya çıkan rekabet durumunda işverene bilgi verilmesi gerekliliğinin azalmasıdır. İşçiler arasındaki rekabet nedeniyle işçiler, rekabeti diğer işçilerin çalışmalarını sabote etmek için bir teşvik olarak görebilmektedirler (Sesselmeier \& Blauermel, 1998: 340). Bu durumda iki konu gündeme gelmektedir. Birincisi, işçi, işveren olmadan, özellikle çalışma yoğunluğu ve asimetrik bilginin de varlı̆̆ı nedeniyle verimliliğine yönelik performansını değiştirebilir. İkincisi yalnızca ekonomik amaçlı optimizasyon sürecini takip eden işçi, ücreti kontrol eden işveren tarafından ikame edilebilmektedir. Bu durumda işveren, piyasa denge seviyesinin üzerinde kalarak verimliliğe dayalı ücreti ile emeğin marjinal verimliliğini belirleyebilmektedir. Bununla birlikte, genel neo-klasik varsayım, ücret seviyesinin, emeğin marjinal ürününün değerine karşılık geldiğini öne sürmektedir.

İşveren tarafından öngörülen avantajlara göre sınıflandırılan verimliliğe dayalı işçi ücretlerini açıklamaya yönelik dört ana yaklaşım bulunmaktadır. Bunlar;

Hediye alışverişi yaklaşımı, normların çalışma davranışını etkilediğini açıklamak için sosyolojik bir yaklaşım kullanır (Akerlof, 1982: 560).

Işsten çıkarma modeli, işçilerin daha yüksek ücret alması durumunda işsiz kalma maliyetinin artacağını ve bunun işçilerin işten atılmaması için bir teşvik oluşturarak işten atılma riskini azalttığını ileri sürer (Shapiro ve Stiglitz, 1984: 442).

Işsgücü devir hızı yaklaşımı, işletmelerin, işçileri değiştirmenin yüksek maliyeti (iş arama, işe alma, eğitim maliyetleri) nedeniyle piyasadaki ücretten daha yüksek ücretler sunduğunu öngörmektedir (Stiglitz, 1974: 230).

Ters seçim perspektifi, işe alma standartlarını artırarak daha verimli bir işgücünü oluşturup teklif edilen yüksek ücretler nedeniyle daha geniş bir başvuru havuzu ile karşı karşıya kalan şirketler için geçerlidir (Weiss, 1980: 530).

Davranışı açıklamaya yönelik diğer yaklaşımların (örneğin oyun teorisi) aksine, söz konusu dört yaklaşım, norm ve duyguların dikkate alınması nedeniyle çok işlevseldir.

Hediye değişiminin sosyal bağlamı da oldukça önemlidir. Bir hediye, alıcı için diğer tarafla takas edilen daha etkileyici bir hediyeye eşdeğer kabul edilen duygusal bir değere sahip olabilir. Bununla birlikte, örneğin bir taraf aldığından daha fazlasını verdiğini hissettiği gibi, hediye alışverişinde bir dengesizlik göründüğünde, mağdur olan taraf değişim sürecine daha 
Davranışsal Çalışma Ekonomisi Alanında Güncel Gelişmeler

fazla odaklanacak ve bu da ilişkiyi olumsuz yönde etkileyebilecektir (Blau, 1964: 197). Bu durumda her iki taraf arasında güven geliştirme potansiyeli azalabildmektedir. Taraflardan herhangi birinin karşılık vermemesi halinde hediye veren tarafın hayal kırıklığı yaşaması ciddi bir risk olușturmaktadır (Blau, 1964: 198).

\section{C- Hediye Değişimi Teorisinin Uygulama Sonuçları}

Hediye değişimi teorisi, şirketlerin işçilere verilebilecek en düşük ücretten daha yüksek bir ücret (bir hediye) ödeyerek çalışma gruplarının normlarını veya ortalama çabayı artırabileceklerini öne sürmektedir. Buna karşılık, iş̧̧ilerin çabası, gerekli asgari çabanın üzerinde gerçekleştiğinde bu durum "hediye alışverişinin normları" olarak tanımlamaktadır (Akerlof, 1990: 262). İşçi açısından verilen hediye işçinin çalışmasıdır ve şirket tarafından verilen hediye ise yüksek işçilik ücreti olarak karşılık bulmaktadır. Dolayısıyla verimlilik unsuru, iki taraf arasındaki normatif bir mutabakat olarak kabul edilmektedir. Bu durumda verimliliğe dayalı ücretin iki özelliği ortaya çıkmaktadır. Birincisi, verimliliğe dayalı ücret işveren tarafından ödenir ve işçi verimliliğe dayalı ücretini aldığı için bir karşılık verir. Bu durum, işçinin bunun için para ödemediği anlamına gelir ancak işçi çalışma davranışını bununla değiștirdiği için ișveren için verimliliğe dayalı ücreti teklif etmeye uygun bir durum oluşturmaktadır. İkincisi, piyasadaki denge ücret ile bu denge ücretin üzerinde ödenen ücretler arasındaki fark, ek ücret açısından bir hediye olarak kabul edilmektedir (Akerlof, 1982: 562). Diğer bir deyişle verimliliğe dayalı ücret politikası, parasal bir teşvik olarak yorumlanmaktadır. Teşviklerin para olarak verilmesi yaygın olmakla birlikte uygulamada sadece parasal teşvikler uygulanmamaktadır. Teşviklerin içeriği değişebilir ve örgütün kültürü, iletişim sistemleri, kişilerarası ilişkileri, konumu ve imajı da olası teşvikler olarak değerlendirilmektedir. Hediye değişimi modeli bağlamında, teşvik piyasada sağlanan standardın ölçülebilir bir unsurudur. Dolayısıyla, şirket tarafından örneğin işçiye çocuk bakım ücreti adı altında bir yan ödeme yapılması halinde bu ödeme işgücü piyasasında bir standart ödeme niteliğinde değilse, şirket tarafından yapılan bu ödeme iş̧̧i tarafından bir hediye olarak kabul edilebilir. Ancak işçiye, şirket tarafından verilen örgütsel eğitimin hediye değişim modeli bağlamında ne ölçüde bir armağan olarak görülebildiği halen tartışılmaktadır (Balkin ve Richiebé, 2007: 56). Bu tartıșma, hediye değișimi teorisinin; bileșenlerinin, verimliliğe dayalı ücretten beklenen getirileri, beklenen getirilerin kaybedilme nedenleri ve hangi tarafın ödeme yapacağı beklentisi kapsamında değerlendirilmektedir.

İşücü piyasasındaki, özellikle içsel işgücü piyasalarındaki heterojenlik, bir hediye uygulanmasında işverenler için önemli bir konudur. Hangi işçilerin hediye alışverişi kapsamında verilen teşviklerle motive edilebileceğinin bilinmesi çok önemlidir. Karşıllıklılık veya eşitsizlikten kaçınma gibi sosyal tercihlerin potansiyel olarak yalnızca işgücü piyasası davranışını şekillendirmediği, aynı zamanda teşvik programlarının da gereken davranışları şekillendirebildiği yaygın olarak kabul edilmektedir (Lepak ve Snell, 2007: 15). Ayrıca, bir hediyenin işçi tarafından ne kadar yeterli veya adil algılandığının da önemi bulunmaktadır. Algılama, işçilerin beşeri sermayesi ve sosyal tercihleri açısından özelliklerine veya şirketin kurumsal özelliklerine bağlı değişebilmektedir. İşverenler, işçilerin tutum ve davranışlarını motive eden insan kaynaklarına dayalı teșviklerini tasarlayıp uygulayabilmektedirler (Falk, 2007: 1510). Bir işverenin belirli teşvikleri uygulama kararı, şirketin uzun vadeli stratejisine bağlı olabilmektedir. Örneğin, bir şirket yenilikçi ürünler geliştirmek istiyorsa, teşvikleri arasında yenilikçi düşünme üzerine atölye çalışmaları yapabilir (Lepak ve Snell, 2007: 17).

Çok sayıda gerçekleştirilen hediye alışverişi saha deneyinde, ücret ve çaba/efor arasında pozitif bir ilişki olduğu gözlemlenmiştir. Amsterdam Üniversitesi'nden 84 lisans öğrencisi ile yapılan bir deney, işçinin yüksek ücret alabilmek için asgari çabasının yalnızca \%23,8'i oranında gerçekleştiği gözlemlenmiştir. Nottingham Üniversitesi'nden 123 öğrenci üzerinde 
yapılan başka bir deneyden elde edilen veriler, işveren tarafından peşin ödenen ücretler karşılığında yüksek ücret alabilmek için öğrencilerin \%69 oranında bir çaba sarfettikleri görülmüştür. Bir başka çalışma iki ayrı grupla yürütülen gönüllülük faaliyeti ile ilgilidir (Gneezy ve List, 2006: 1340). Bu faaliyetlerden birisi kütüphane kayıtlarına sayısal bilgi girmek diğeri bir vakıf için para toplamak şeklindedir. Söz konusu faaliyetleri yürüten bir gruba yüksek ücret verilmiş diğer gruba yüksek ücret verilmemiştir. Faaliyetler tamamlandığında her iki grubun işgücü verimliliklerine yönelik veriler karşılaştırılmıştır. Sonuç olarak yüksek ücret alan grubun başlangıçta iyi performans gösterdiği ancak daha sonra performanslarının çok düştüğü görülmüştür. Nihayet ücret başına verimlilik hesabı yapıldığında, yüksek ücret alan grubun karşılıklı davranış ilkesine göre verimli olma performansının düşük ücret alan gruptan daha düşük olduğu yani zaman ilerledikçe tercihli işlem isteğinin olağan bir durum olarak kabul edildiği ve bu nedenle işçileri yüksek ücret ödenmiş olmasına rağmen belli bir süre sonra çalışma isteklerinin azalabileceği görülmüştür.

Davranışsal ekonomi alanındaki gelişmeler makro ekonomi alanında laboratuar/deneysel çalışmaları da arttırmıştır. Bu kapsamda çalışma ekonomisi alanında hediye değişimi modeli çerçevesinde, ücret belirlemede doğruluk ve karşılıklılık ilkelerinin rolünün ölçülmesi amacıyla deneysel çalışmalarda yapılmıştır (Fehr ve Gächter, 2000: 161). Bu deneylerde, minimum gayret beklentisi ile şirketlerin minimum ücret ödediği standart ahlaki çöküntü modelleri ve şirketin prim olarak yüksek ücret ödediği ve yüksek gayretle ödüllendirildiği etkin ücret modelleri arasında deneysel karşılaştırmalar yapılmıştır. Ortaya çıkan pozitif ücret-çaba/efor ilişkisi, eksik sözleşmelerin uygulandığı alanlarda sorunların çözülmesine yardımcı olmuştur. Çaba unsuru genellikle gözlemlenemediğinden veya üçüncü taraflarca uygulanamaz olduğundan karşılıklılık ilkesi kapsamında hediye değișimi oyununu kullanmanın işgücü piyasası ile ilgili deneysel sonuçları olumlu yönde etkilediği görülmüştür (Fehr ve Falk, 1999: 117). Aşırı işgücü arzının olduğu bir piyasada faaliyet gösteren şirketlerin, işçilerin çaba seviyelerini temel aldıkları iş sözleşmeleri yapılmadığında düşük ücret karşılığında çalışmayı teklif eden işçilerle sözleşme yapılamadığı görülmüştür. $\mathrm{Bu}$ durum, işçilerin çaba marjları içinde uyum sağlayamasalar bile bu işçilerin çalışma taleplerinin reddedilmediğini göstermektedir. $\mathrm{Bu}$ bulgu, işverenlerin; işçilerin çaba seviyelerinin sözleşmelere yansıtılamaması nedeniyle düşük ücretle çalışmaları halinde düşük ücretlere tepki olarak işçilerin morallerinin bozulmasından korktuklarını ortaya koymuştur. Hediye değişimi oyunu kapsamında işgücü piyasalarında yürütülen deneysel çalışmalar aracılığıyla işgücü piyasasında faal olan kurumların etkisi, şirketlerin ücret belirleme davranışları, uzun vadeli istihdam ilişkilerinin oluşumunun, gayrı iradi işsizliğin, asgari ücret düzenlemelerinin ve istihdam koruma mevzuatının etkileri incelenmiştir ( Falk vd., 2008: 13; Fehr ve Falk, 2002, Abeler vd., 2010: 1310; Brown vd., 2004: 754). Çaba sarfetmenin adalet güdülerine bağlı olduğu ve karşılıklılıktan etkilendiği savı, çalışma ekonomistleri tarafından benimsenmiştir. Deneysel çalışmalar, işgücü piyasalarında oluşan adalet normlarının ve karşılıklılık ilişkisinin; davranışları yönlendirdiğini, ücret katılığının oluşmasına ve gayrı iradi işsizliğin ortaya çıkmasına yol açtığını ortaya koymuştur (Akerlof, 1982: 560; Altmann vd. 2014: 41). Bununla birlikte, bu güdülerin gerçek saha çalışmalarındaki sonuçları da etkileyip etkilemediği konusunda bir tartışma bulunmaktadır (Levitt ve List, 2007: 160). Örneğin bir ağaç dikme işi yapan şirkette yürütülen bir saha deneyinde, işçilerin verimlilikleri ile ilgisi olmayan beklenmedik bir bonus ödemesi yapılmasının, işçilerin verimlilikleri üzerinde olumlu bir etkiye sahip olduğu görülmüştür (Bellemare ve Shearer, 2009: 238). Ancak beklenmedik bir ücret artışının yalnızca kısa süreli olumlu bir etkisinin olduğu da öne sürülmüştür (Gneezy ve List, 2006: 1371). Ayrıca parasal olmayan hediyelerin, parasal hediyelere göre işçilerin çabalarını daha çok arttırdığı gözlenmiştir (Kube vd., 2013: 861). Ancak genel olarak, ücret artışlarının etkilerinin tartışmalı olduğu ve bu etkilerin duruma göre değiştiği kanaati yaygındır. 
İşgücü piyasalarından elde edilen kanıtlar, karşılıklılık, adalet ve sosyal tercih unsurlarının hediye alışverişi ile bağlantılı olduğunu ispat etmiştir (Bandiera vd., 2005: 940). İşçilerin, iş arkadaşları ile sosyal etkileşimlerinin olumlu yönde gelişmesi durumunda işçinin çabasının arttığı ayrıca fazla çalışma ile pozitif karşılıklılık arasında pozitif bir korelasyon olduğuna dair yapılan bir anket çalışması önemli kanıtlar sunmuştur (Dohmen vd., 2009: 600). Büyük bir uluslararası şirketin işçi verileri analiz edildiğinde, göze çarpan bir referans noktasının altında prim alan yöneticilerin daha sonra performanslarının düşmesi halinde bu referans noktasının adil işlem yapmak için norm oluşturduğunu varsaydıkları, işverenlerin bu tür adalet unsurlarının farkında olduklarına dair çok sayıda kanıt bulunmaktadır (Ockenfels vd., 2014: 1501). Yine yöneticiler arasında yapılan bir araştırma, yöneticilerin, nominal ücret kesintilerini bir hakaret veya düşmanca bir eylem olarak yorumlayan işçilerin kızgınlıklarından korkmaları nedeniyle işçi ücretlerini düşürmekten kaçındıklarını ortaya koymaktadır. (Bewley, 1999: 104; Agell ve Lundborg, 2003: 18). Dolayısiyla, haksiz muameleye yanıt olarak misilleme korkusu, aşağı yönlü nominal ücret katılığının önemli bir nedeni olarak görünmektedir (Bewley, 2007: 34). İşçilerin haksız muameleye tepkisinin ana itici gücü olarak olumsuz karşılıklılığı tanımlayarak, haksız olarak algılanan bir emeklilik reformuna yanıt olarak iş motivasyonundaki azalmanın, onların olumsuz karşıllıklılık eğilimine bağlı olduğunu göstermiştir (Montizaan vd., 2012: 671)

Ücretlerin aniden artırıldığı bir işyerinde, başlangıçtaki çaba düzeyi işçilerin adalet algılarına bağlıdır. Ücret artışının yetersiz olduğunu düşünerek ücret artışını sağlamak için çabalarını arttıran işçiler ücret artışına güçlü tepki verirken minimum ücreti zaten adil olarak algılayan işçiler, ücrete yanıt olarak çabalarını daha fazla arttırmamışlardır (Kube vd., 2012: 1650). Ücret artışlarının performans üzerinde çok az etkisi olduğu ancak ücret kesintilerinin verimlilik üzerinde zararlı ve kalıcı bir etkisi olduğu görülmüştür (Mas, 2006: 800).

New Jersey'deki polis sendikalarının taraf olduğu toplu sözleşme görüşmeleri sırasında son ücret teklifine yanıt olarak polislerin performansının kötüleştiği tespit edilmiştir (Mas, 2006: 796). Yine bir işçi sendikası ile Caterpillar şirketi arasındaki görüşmelerde, teklif edilen ücretin işçiler tarafindan beğenilmemesi sonucu görüşmeler devam ederken o dönemde Caterpillar tarafından üretilen inşaat ekipmanlarının üretiminin hem sayıca hem de kalite olarak düşük olarak gerçekleştiği gözlenmiştir (Kube vd., 2013: 860). Ayrıca veri girişinin yapıldığı bir işte, ücret kesintilerinin veri girişi işinde çalışan işçilerin verimliliği üzerinde zararlı ve kalıcı bir etkiye sahip olduğu, buna karşılık işçiler üzerinde eşdeğer bir ücret artışının hiçbir etkisinin olmadığı kanıtlanmıştır. Hollanda'da kamu sektörü işçilerinin emeklilik haklarını kısıtlayan bir emeklilik reformunun çalışma moralini nasıl etkilediğini incelemek için yapılan bir araştırma sonucunda, reformdan etkilenen yaşlı işçilerin reformdan etkilenmeyen işçilere göre motivasyonlarının önemli ölçüde düştüğü gözlenmiştir. $\mathrm{Bu}$ durum, çalışma motivasyonundaki azalmanın ciddiyetinin, karşılıklı olumsuz eğilimlerin gücüne bağlı olduğunu, olumsuz karşılıklılık eğilimiyle algılanan haksız muameleye karşı işçilerin verdiği tepkinin azalmasının şiddeti arasındaki bağlantı olduğunu ortaya koymuştur (Kube, vd. 2013: 861).

\section{SONUÇ}

İşveren, adil ücret hipotezi çerçevesinde, emsal işçi ücretlerinden daha yüksek ücret ödediğinde işçiler daha fazla çaba göstererek işvereni ödüllendirirlerse ortaya çıkan pozitif ücret-çaba/efor ilişkisi, eksik sözleşme uygulamalarına ilişkin sorunları çözebilmektedir. Hediye değişimi teorisi, verimsizliğin, eksik rekabet şartlarına veya psikolojik faktörlerle ilişkili olarak devamlılık gösterebileceğini ileri süren Leibenstein'ın X-etkinsizliği teorisi ile doğrulanmaktadır. İşgücü piyasalarında eksik sözleşmeler nedeniyle, çaba sağduyusu işçilerin performansını belirlemede önemli bir rol oynamaktadır. Bireyin çaba alanı, bireyi 
yönlendiren iç ve dış faktörler tarafından belirlenmektedir. $\mathrm{Bu}$ nedenle çabadaki değişiklikler, psikolojik faktörlerin ve ekonomik faktörlerin etkileşimi ile belirlenmektedir. Böylece işveren, işçilere emsal işçi ücretinden daha yüksek ücret ödeyebilmektedirler.

Hediye değişimi teorisi; şirketlerin işe alma kararlarını, ücret belirleme davranışlarını, ücret katılığını, gayrı iradi işsizliği ve asgari ücret yasalarının etkileri de dahil olmak üzere, deneysel işgücü piyasası sonuçlarında işgücü piyasası kurumlarının etkisini incelemek için yoğun bir şekilde kullanılmaktadır. Bu çalışmaların temel bulguları şu şekildedir: Birincisi, ücret artışı ile çaba/efor artar, ikincisi, çaba ücret kesintilerine, ücret artışından daha duyarlıdır ve üçüncüsü, şirketler emsal ücretlerden daha yüksek ücretler ödeyebilirler.

Hediye değişim teorisi ile birlikte geleneksel ekonomiden farklı olarak, gayrı iradi işsizlik halinde etkin ücret için ampirik olarak doğruluk ve karşılıklılığa (reciprocity) dayanan psikolojik açıklamalar davranışsal çalışma ekonomisi alanına ilişkin literatüre girmiştir. Hediye değişimi teorisi, gayrı iradi işsizlik halinde bazı şirketlerin piyasanın denge ücretinin üzerinde ücret ödediklerini ortaya koymaktadır. Ayrıca söz konusu teori, karş1lıklılık ve doğruluk prensibi çerçevesinde işçilerin daha fazla gayret göstermesi yönünde işverenlerin beklentisinin olduğunu açıklayarak psikolojik faktörlerin rekabetçi işgücü piyasasında ücret ve istihdamı etkileyebileceği ortaya konmuştur. Hediye alışverişi perspektifinin, işyerindeki söz konusu sosyal etkileşimleri tanımlamak için iyi bir uygulama olduğu ispat edilmiştir.

Asil-vekil ilişkisinde, teşvik problemini en iyi birinci çözümüne götüren hediye değişiminin altında içsel motivasyon olgusu yer almaktadır. Ekip çalışmasında, hediye alışverişi, ekip üyelerinin bireysel performansını ölçme ihtiyacını ortadan kaldırmaktadır. Çalışma gruplarında hediye vermenin iki ana nedeni olarak sosyal onay ve adalet kavramları karşımıza çıkmaktadır. İşçiler hediye alışverişi ilişkilerinde yer alıyorsa, o zaman Paretooptimal bir üretim seviyesine ulaşılabilir. Hediye değişim ilişkisindeki en önemli rol, hediyelerin şekil ve değer açısından birbirleriyle eşleştirilmesini temsil eden hediyelerin yeterlilik oranıdır. Herhangi bir işyerinde, hediye değişiminin önemli bir rol oynayabileceği ve standart resmi sözleşme ilişkileri kapsamında geliştirilebileceği açıkça ispatlanmıştır. Bu nedenle, hediye alışverişi, asil-vekil ilişkisi analizini zenginleştirerek işyerindeki belirli özgecil fenomeni ve daha yüksek ortak verimlilik seviyelerinde açıklamaktadır.

\section{Kaynakça}

Abeler, J., Altmann, S., Kube, S. ve Wibral, M. (2010). Gift Exchange and Workers-Fairness Concerns: When Equality is Unfair. Journal of the European Economic Association. 8(6). 1299-1324.

Agell, J. ve Lundborg, P. (2003). Survey Evidence on Wage Rigidity and Unemployment. Scandinavian Journal of Economics. 105(1). 15-30.

Akerlof, G. A. (1982). Labor Contracts as Partial Gift Exchange. The Quarterly Journal of Economics. 97(4). 543-569.

Akerlof G. A. (1984). Gift Exchange and Efficiency-Wage Theory: Four Views. American Economic Review. 74(2). 79-83.

Akerloff, G. A. ve Yellen, J. (1990). The Fair Wage-Effort Hypothesis and Unemployment. Quarterly Journal of Economics. 105(2). 255-283.

Akerlof, G. A. (2003). Behavioral Macro Economics and Macroeconomic Behavior. The American Economist. 47(1). 25-47.

Akerlof, G. A. ve Shiller, R. J. (2009). Animal Spirits: How Human Psychology Drives the Economy and Why It Matters for Global Capitalism. Princeton University Press. ABD. 
Almlund, M., Duckworth, A. L., Heckman, J. J. ve Kautz, D. (2011). Personality Psychology and Economics. (In E. A. Hanushek, S. Machin, and L. Wößmann (Eds.), Handbook of the Economics of Education. Elsevier. Amsterdam.

Altmann, S., Falk, A., Grunewald, A. ve Huffman D. (2014). Contractual Incompleteness, Unemployment and Labour Market Segmentation. Review of Economic Studies. 81(2). 30-56.

Babcock, L., Loewenstein G. ve Wang X. (1995). The Relationship Between Uncertainty, The Contract Zone and Efficiency in a Bargaining Experiment. Journal of Economic Behavior and Organization. 27 (1). 475-485.

Babcock, L., Wang, X. ve Loewenstein G. (1996). Choosing the Wrong Pond: Social Comparisons in Negotiations that Reflect a Self-Serving Bias. Quarterly Journal of Economics. 111(1). 1-19.

Babcock, L., Congdon, W. J., Katz, L. F ve Mullainathan, S. (2012). Notes on Behavioral Economics and Labor Market Policy. Journal of Labor Policy. 1(2).1-14.

Balkin, D. B. ve Richebe, N. (2007). A Gift Exchange Perspective on Organizational Training. Human Resources Management Review. 17 (1). 52-62.

Bandiera, O., Barankay, I. ve Rasul, I. (2005). Social Preferences and the Response to Incentives: Evidence from Personnel Data. Quarterly Journal of Economics. 120(3). 917-62.

Barmby, T. ve Dolton, P. (2009). What Lies Beneath? Effort and Incentives on Archaeological Digs in the 1930's. Standford University Press. ABD.

Bartling, B. ve Von Siemens, F. (2010). The Intensity of Incentives in Firms and Markets: Moral Hazard with Envious Agents. Labour Economics. 17 (1). 598-607.

Bellemare, C. ve Shearer, B. (2009). Gift Giving and Worker Productivity: Evidence From a FirmLevel Experiment. Games and Economic Behavior. 67(1). 233-244.

Berg, Joyce, Dickhaut, J. ve McCabe, K. (1995). Trust, Reciprocity and Social History. Games and Economic Behavior. 10 (1). 122-142.

Berg, N. (2006). Behavioral Labor Economic. (In M. Altman (Ed.), Handbook of Contemporary Behavioral Economics) M. E. Sharpe. New York.

Bewley, T. F. (1999). Why Wages Don't Fall During a Recession. Harvard University Press. Cambridge, MA.

Blau, P. M. (1964). Justice in Social Exchange. Sociological Inquiry. 34(2).193-206.

Bolton, G. ve Ockenfels, A. (2000). ERC: A Theory of Equity, Reciprocity and Competition. American Economic Review. 90 (1). 166-93.

Borghans, L., Duckworth, A.L, Heckman, J. J. ve Ter Weel, B. (2008). The Economics and Psychology of Personality Traits. Journal of Human Resources. 43(4).972-1059.

Bowles, S., Gintis, H. ve Osborne, M. (2001). The Determinants of Earnings: A Behavioral Approach. Journal of Economic Literature. 39(4). 1137-1176.

Brown, M., Falk, A. ve Fehr, E. (2004). Relational Contracts and The Nature of Market Interactions. Econometrica. 72(3). 747-780.

Camerer, C. F., Samuel, I., Loewenstein, G., O’Donoghue, T. ve Rabin, M. (2003). Regulation For Conservatives: Behavioral Economics and the Case for Asymmetric Paternalism. University of Pennsylvania Law Review. 151(1). 1211-54.

Camerer, C. F., Babcock, L., Loewenstein, G. ve Thaler, R. (1997). Labor Supply of New York City Cabdrivers: One Day At a Time. The Quarterly Journal of Economics. 112(2). 407-441. 
Camerer, C. F. (2006). Behavioral Economics. (In: Blundell, R., Newey, W.K., Persson, T. (Eds.). Advances in Economics and Econometrics: Theory and Applications, Ninth World Congress. Vol. 2., Cambridge and New York: Cambridge University Press.

Card, D., Mas, A., Moretti, E. ve Saez, E. (2012). Inequality at Work: The Effect of Peer Salaries on Job Satisfaction. American Economic Review. 102(6). 2981-3003.

Charness, G. ve Rabin, M. (2002). Understanding Social Preferences with Simple Tests. Quarterly Journal of Economics. 117(3). 817-69.

Charness, G. (2004). Attribution and Reciprocity in an Experimental Labor Market. Journal of Labor Economics. 22(3). 665-688.

Charness, G., Cobo-Reyes Ramón, R., Jiménez, N., Lacomba, L. N., Juan, A ve Lagos, F. (2012). The Hidden Advantage of Delegation: Pareto Improvements in a Gift Exchange Game. American Economic Review. 102(5). 2358-2379.

Charness, G. ve Kuhn, P. (2011). Lab Labor: What Can Labor Economists Learn From the Lab? Handbook of Labor Economics. 4(1). 229-330.

Chou, Y. K. (2002). Testing Alternative Models of Labor Supply: Evidence from Cab Drivers in Singapore. The Singapore Economic Review. 47(1). 17-47.

Clark, A. E., Masclet, D. ve Villeval, M. C. (2010). Effort and Comparison Income: Experimental and Survey Evidence. Industrial and Labor Relations Review. 63(3). 407-426.

Cohn, A., Fehr, E., Herrmann, B. ve Schneider, F. F. (2014). Social Comparison and Effort Provision: Evidence from a Field Experiment. Journal of the European Economic Association. 12(4). 877-98.

Cox, J. C., Sadiraj, K. ve Sadiraj, V. (2008). Implications of Trust, Fear and Reciprocity for Modeling Economic Behavior. Experimental Economics. 11 (2). 1-24.

Crawford, V. P. ve Meng, J. (2011). New York City Cab Drivers' Labor Supply Revisited: Reference Dependent Preferences with Rational Expectations Targets for Hours and İncome. American Economic Review. 101(5). 1912-1932.

DellaVigna, S. (2009). Psychology and Economics: Evidence From the Field. Journal of Economic Literature. 47(2). 315-372.

Demirel, S. K. ve Artan, S. (2016). Nöroekonomi ve İktisat Biliminin Geleceğine İlişkin Tartışmalar. Uluslararası İktisat ve Yenilik Dergisi. 2(1). 2-19.

Dodlova M. ve Yudkevich, M. (2009). Gift Exchange in the Workplace. Human Resource Management Review. 19(1). 23-38.

Dohmen T., Falk, A., Huffman, D ve Sunde, U. (2009). Homo Reciprocans: Survey Evidence on Behavioral Outcomes. Economic Journal. 119(536). 592-612.

Dohmen, T. (2014). Behavioral Labor Economics: Advances and Future Directions. National Report Germany. IZA DP No: 8263.

Doran, K. B. (2009). The Existence and Position of Daily İncome Reference Points: Implications for Daily Labor Supply. Discussion Paper. University of Notre Dame.

Dufwenberg, M. ve Kirchsteiger, G. (2004). A Theory of Sequential Reciprocity. Games and Economic Behavior. 47(2). 268-98.

Falk, A. ve Fischbacher, U. (2006). A Theory of Reciprocity. Games and Economic Behavior. 54(2). 293-315.

Falk, A. ve Ichino, A. (2006). Clean Evidence on Peer Effects. Journal of Labor Economics. 24(1). 39-57.

Falk, A. (2007). Gift Exchange in the Field. Econometrica. 75(5).1501-1511. 
Falk, A., Huffman, D. ve MacLeod, W. B. (2008). Institutions and Contract Enforcement. National Bureau of Economic Research. No: w13961.

Farber, H. S. (2008). Reference-Dependent Preferences and Labor Supply: The Case of New York City Taxi Drivers. The American Economic Review. 98(3). 1069-1082.

Fehr, E., Kirchsteiger, G. ve Riedl, A. (1993). Does Fairness Prevent Market Clearing? An Experimental Investigation. The Quarterly Journal of Economics. 108(2). 437-459.

Fehr, E. ve Gächter, S. (1998). Reciprocity and Economics: The Economic Implications of Homo Reciprocans. European Economic Review. 42(3-5). 845-859.

Fehr, E. ve Falk, A. (1999). Wage Rigidity in a Competitive Incomplete Contract Market. Journal of Political Economy. 107(1). 106-134.

Fehr, E. ve Gächter, S. (2000). Fairness and Retaliation. Journal of Economic Perspectives. 14(3). 159181.

Fehr, E. ve Goette, L. (2007). Do Workers Work More if Wages Are High? Evidence From a Randomized Field Experiment. American Economic Review. 97(1). 298-317.

Fehr, E., Goette, L. ve Zehnder, C. (2009). A Behavioral Account of the Labor Market: The Role of Fairness Concerns. Annual Review of Economics. 1(2). 355-384.

Frank, R. H. (2005). Positional Externalities Cause Large and Preventable Welfare Losses. American Economic Review. 95 (2). 137-141.

Frohlich, N., Oppenheimer, J. ve Kurki, A. (2004). Modeling Other-Regarding Preferences and an Experimental Test. Public Choice. 119(3). 91-117.

Gächter, S., Daniele, D. ve Sefton, M. (2012). The Impact of Social Comparisons on Reciprocity. The Scandinavian Journal of Economics. 114(4). 1346-1367.

Gneezy, U. ve List, J. A. (2006). Putting Behavioral Economics to Work: Testing for Gift Exchange in Labor Markets Using Field Experiments. Econometrica. 74(5). 1365-1384.

Grossman, S. J. ve Hart, O. D. (1986). The Costs and Benefits of Ownership: A Theory of Vertical and Lateral İntegration. Journal of Political Economy. 94(4). 691-719.

Gul, F. (2008). Behavioural Economics and Game Theory. The New Palgrave Dictionary of Economics. (Eds. Steven N. Durlauf and Lawrence E. Blume). The New Palgrave Dictionary of Economics Online. Palgrave Macmillan.

Hamilton, III., Robert, D. ve Kashlak, Roger, J. (1999). National Influences on Multinational Corporation Control System Selection. Management International Review. 39(2). 167-189.

Heijden, E., Nelissen, J., Potters, J. ve Verbon, H. (2001). Simple and Complex Gift Exchange in the Laboratory. Economic Inquiry. 39(2). 280-297.

Kahneman, D., Knetsch, J. ve Thaler, R. (1986). Fairness and the Assumptions of Economics. Journal of Business. 59(3). 285-300.

Kahneman, D. ve Tversky, A. (1979). Prospect Theory: An Analysis of Decision Under Risk. Econometrica. 47(2). 263-291.

Kamilçelebi, H. (2019). Davranışsal İktisat. London: IJOPEC Publication.

Karayel, M. (2006). Türkiye'de İşletmelerde Kurumsal Yönetişim Bilincinin Ölçülmesine İlişkin Batı Akdeniz Bölgesi'nde Bir Araştırma. Yüksek Lisans Tezi. Süleyman Demirel Üniversitesi. Sosyal Bilimler Enstitüsü. Isparta.

Kaufman, B. E. (1999). Expanding the Behavioral Foundations of Labor Economics. Industrial and Labor Relations Review. 52(1). 361-392. 
Kőszegi, B. ve Rabin, M. (2006). A Model of Reference-Dependent Preferences. Quarterly Journal of Economics. 121(4). 1133-65.

Kranton, R. (1996). Reciprocal Exchange: A Self-Sustaining System. American Economic Review. 86(4). 830-851.

Kriss, P., Loewenstein, G., Wang, X ve Weber, R. (2011). Behind the Veil of Ignorance: Self-Serving Bias in Climate Change Negotiations. Judgment and Decision Making. 6(7). 602-15.

Krueger, A. B. ve Mas, A. (2004). Strikes, Scabs and Tread Separations: Labor Strife and the Production of Defective Bridgestone/Firestone Tires. Journal of Political Economy. 112(2). 253-289.

Kube, S., Puppe, C. ve Maréchal, M. A. (2012). The Currency of Reciprocity - Gift-Exchange in the Workplace. American Economic Review. 102(4).1644-1662.

Kube, S., Maréchal, M. A. ve Puppe, C. (2013). Do Wage Cuts Damage Work Morale? Evidence from a Natural Field Experiment. Journal of the European Economic Association. 11(4). 853-870.

Ledyard, J. O. (1995). Public Goods: A Survey of Experimental Research (In: J. Kagel and A. Roth) Handbook of Experimental Economics. NJ: Princeton University Press.

Lepak D. P. ve Scott, A.S. (2007). Employment Subsystems and the 'HR Architecture, The Oxford Handbook of Human Resource Management. (Ed. Peter F. Boxall, John Purcell and Patrick M. Wright.) Oxford University Press.

Levitt, S. ve List, J. A. (2007). What Do Laboratory Experiments Measuring Social Preferences Reveal About the Real World? Journal of Economic Perspectives. 34(2).153-174.

List, J. A. ve Rasul, I. (2011). Field Experiments in Labor Economics. Handbook of Labor Economics. 132(1). 104-213.

Liu, K. ve Wang, X. (2015). Relative Income and Income Satisfaction: An Experimental Study. Social Indicators Research. 21(3). 395-409.

Luttmer, E. (2005). Neighbors as Negatives: Relative Earnings and Well-Being. Quarterly Journal of Economics. 120(3). 963-1002.

Mas, A. (2006). Pay, Reference Points and Police Performance. Quarterly Journal of Economics. 121(3). 783-821.

Messick D. ve Sentis, K. (1979). Fairness and Preference. Journal of Experimental and Social Psychology. 15(1). 418-435.

Montizaan, R., Cörvers, F., De Grip, A. ve Dohmen, T (2012). Negative Reciprocity and Retrenched Pension Rights, IZA Discussion Paper No: 6955.

Mullainathan, S. ve Thaler, R. H. (2000). Behavioral Economics. NBER Working Paper Series No: 7948 .

Neumark, D. ve Postlewaite, A. (1998). Relative Income Concerns and the Rise in Married Women's Employment. Journal of Public Economics. 70(1). 157-183.

Ockenfels A., Sliwka, D. ve Werner, P. (2015). Bonus Payments and Reference Point Violations. Management Science. 61(7). 1496-1513.

Olson, J. M., Herman, C. P ve Zannan, M. P. (2005). Relative Deprivation and Social Comparison. Psychology Press. Newyork.

Özdemir, Ş. (2019). Bir Kamu Politikası Aracı Olarak Davranışsal İçgörü. Türkiye İletişim Araştırmaları Dergisi. 34(2). 247-274.

Shapiro, C. ve Stiglitz, J. (1984). Equilibrium Unemployment as a Worker Discipline Device. The American Economic Review. 74(3). 433- 444. 
Smelser, Neil, J. ve Swedberg, R. (2013). İktisat Sosyolojisi. Sentez Yayınc1lk. Bursa

Stark, O. ve Hyll, W. (2011). On the Economic Architecture of the Workplace: Repercussions of Social Comparisons Among Heterogeneous Workers. Journal of Labor Economics. 29(2). 349-375.

Stiglitz, J. (1974). Incentives and Risk Sharing in Sharecropping. Review of Economic Studies. 41(2). 219-255.

Tagiew, R. ve Dmitry, I. (2016). Gift Ratios in Laboratory Experiments. CEUR Workshop Proceedings. CLA-2016. Experimental Economics and Machine Learning. Vol.1627. 82-93.

Thaler, R. H ve Sunstein, C. R. (2017). Dürtme. Pegasus Yayınları: İstanbul

Ubeda, P. (2010). The Consistency of Fairness Rules: An Experimental Study. Journal of Economic Psychology. 41(4). 88-100.

Wang, X. (2012). When Workers Do Not Know: The Behavioral Effects of Minimum Wage Laws Revisited. Journal of Economic Psychology. 33(2). 951-962.

Weiss, A. (1980). Job Queues and Layoffs in Labor Markets With Flexible Wages. Journal of Political Economy. 88(3). 526-538.

Winter-Ebmer, R. (2014). What is (not) Behavioral in Labor Economics. Labor Economics. 30(1). 86-87. 